\title{
PENGARUH MODEL POGIL DAN GAYA KOGNITIF TERHADAP HASIL BELAJAR IPA PADA SISWA KELAS V SD
}

\author{
Ketut Andi Prahasta, I Made Tegeh \\ Jurusan Pendidikan Guru Sekolah Dasar, Fakultas Ilmu Pendidikan \\ Universitas Pendidikan Ganesha, Jln. Udayana No. 11 Singaraja \\ e-mail: andiprash94@gmail.com
}

\begin{abstract}
This research was aimed to analyze the effect of Process Oriented Guided Inquiry Learning (POGIL) and cognitive style's toward science learning achievement. This research is quasi experiment with the post-test only control design. The populations of this research is all of the fifth grade students in elementary school belonging of the Santalia's Group II of Kubutambahan District in academic years 2015/2016 which totally 234 students. The sample was taken out of two classes using random sampling technique. The collected data were analyzed by descriptive statistic, and ANAVA AB. All of the analysis process helped by SPSS 16.0 for windows. The result of the research showed that (1) there are significance differences of the science learning achievement between student's group which studied with POGIL models and student's group which studied with conventional learning. $\left(F_{\text {hitung }}=64,736\right.$ with $s i g=0,000)$, (2) there are significance differences of the science learning achievement between student's group which have reflective cognitive styles and student's which have impulsive cogntive styles. $\left(F_{\text {hitung }}=80,690\right.$ with $\left.\mathrm{sig}=0,000\right)$, and (3) there are significance interaction between POGIL models and cognitive styles toward the science learning achievement $\left(\mathrm{F}_{\text {hitung }}=5,432\right.$ with sig $\left.=0,023\right)$ at SD N 1 Kubutambahan and SD N 6 Kubutambahan. So, there is the influence of POGIL model's and cognitive style's toward science learning achievement.
\end{abstract}

Keywords: POGIL models, cognitive styles, science learning achievement.

\begin{abstract}
ABSTRAK: Penelitian ini bertujuan untuk mengetahui pengaruh model POGIL dan gaya kognitif terhadap hasil belajar IPA. Penelitian ini tergolong quasi experiment dengan rancangan the post-test only control design. Populasi penelitian adalah siswa kelas V SD Negeri di Gugus II Santalia Kecamatan Kubutambahan tahun pelajaran 2015/2016 yang berjumlah 234 orang. Sampel penelitian dipilih dengan teknik random sampling. Data yang telah dikumpulkan dianalisis menggunakan statistik deskriptif, dan ANAVA AB. Proses analisis seluruhnya dibantu oleh SPSS 16.0 for windows. Hasil penelitian menunjukkan (1) terdapat perbedaan yang signifikan hasil belajar IPA antara kelompok siswa yang dibelajarkan dengan model POGIL dan kelompok siswa yang dibelajarkan dengan pembelajaran konvensional $\left(\mathrm{F}_{\text {hitung }}=64,736\right.$ dengan sig $\left.=0,000\right)$. (2) Terdapat perbedaan yang signifikan hasil belajar IPA antara kelompok siswa yang memiliki gaya kognitif reflektif dan kelompok siswa yang memiliki gaya kognitif impulsif $\left(\mathrm{F}_{\text {hitung }}=80,690\right.$ dengan $\left.s i g=0,000\right)$. (3) Terdapat interaksi yang signifikan antara model POGIL dan gaya kognitif terhadap hasil belajar IPA $\left(\mathrm{F}_{\text {hitung }}=5,432\right.$ dengan $\left.s i g=0,023\right)$ di SD N 1 Kubutambahan dan SD N 6 Kubutambahan. Jadi, terdapat pengaruh model POGIL dan gaya kognitif terhadap hasil belajar IPA.
\end{abstract}

Kata-kata kunci: Model POGIL, gaya kognitif, hasil belajar IPA. 
Pendidikan memiliki peranan penting dalam membangun masyarakat yang cerdas, damai, terbuka dan demokratis. Pendidikan merupakan kebutuhan yang mendasar bagi setiap individu, oleh karena itu pembaharuan pendidikan harus selalu dilakukan untuk meningkatkan kualitas pendidikan. Dewasa ini diperlukan adanya suatu proses pembelajaran yang baik agar pendidikan dapat berjalan dengan baik sesuai dengan tujuannya. Proses pembelajaran yang bermutu tentu akan menghasilkan output (Sumber Daya Manusia) yang lebih bermutu. Pendidikan merupakan salah satu faktor penting dalam kemajuan suatu bangsa. Pendidikan adalah "salah satu bentuk perwujudan kebudayaan manusia yang dinamis dan sarat perkembangan" (Ibnu, 2014). Pendidikan adalah proses pemberdayaan, yang diharapkan mampu memberdayakan peserta didik menjadi manusia yang cerdas, manusia berilmu dan berpengetahuan, serta manusia terdidik (B. Uno 2011).

Dewasa ini, dunia pendidikan banyak dirundung masalah baik internal maupun eksternal. Hal ini sejalan dengan pendapat Susanto (2013:165-166) menyatakan salah satu masalah yang dihadapi dunia pendidikan saat ini adalah masalah lemahnya pelaksanaan proses pembelajaran yang diterapkan para guru di sekolah. Kondisi ini juga menimpa pada pembelajaran IPA, yang memperlihatkan bahwa selama ini proses pembelajaran SAINS di sekolah dasar masih banyak yang dilaksanakan secara konvensional. Para guru belum sepenuhnya melaksanakan pembelajaran secara aktif dan kreatif dan melibatkan siswa secara aktif dalam proses pembelajaran.

Dalam proses pembelajaran guru masih mendominasi pembelajaran atau dengan kata lain guru masih satu-satunya sumber informasi atau satu-satunya sumber belajar. Guru seharusnya melibatkan peserta didik secara aktif dalam pembelajaran guna mencapai tujuan pembelajaran dan guna informasi atau pengetahuan yang diperoleh dapat bertahan lama.

Mata pelajaran IPA merupakan "mata pelajaran yang selama ini dianggap sulit oleh sebagian besar peserta didik, mulai dari jenjang sekolah dasar sampai sekolah menengah" (Susanto, 2013:165). Anggapan sebagian besar peserta didik yang menyatakan bahwa pelajaran IPA ini sulit adalah benar terbukti dari hasil perolehan Ujian Tengah Semester (UTS) yang rendah yang didapatkan dari sedolah dasar yang ada di Gugus II Santalia berdasarkan observasi yang dilakukan.

Berdasarkan observasi yang telah dilakukan, pada tanggal 15 Januari sampai dengan 18 Januari 2015 di SD Gugus II Santalia Kecamatan Kubutambahan, terdapat beberapa masalah yang terjadi pada proses pembelajaran terutama pada mata pelajaran IPA yang berdampak pada hasil belajar siswa yang belum optimal. Masalah tersebut diantaranya, pertama, rendahnya hasil belajar peserta didik dalam mengikuti pelajaran IPA dapat dipengaruhi oleh beberapa faktor, salah satunya yaitu kebanyakan guru saat ini dalam proses pembelajaran masih tetap setia pada pembelajaran konvensional yang mana pembelajaran ini lebih menekankan teacher centered ketimbang student centered.

Kedua, dalam proses pembelajaran dorongan dari dalam diri siswa untuk berusaha menguasai pembelajaran praktik dan memperoleh hasil yang lebih baik juga dirasakan belum merata, dalam artian masih ada beberapa siswa yang belum memiliki hasrat atau keinginan kuat untuk belajar dan menjadi lebih baik, tanggung jawab terhadap penyelesaian tugas masih kurang.

Ketiga, hal lain yang dapat menyebabkan rendahnya hasil belajar IPA siswa sekolah dasar kelas V, antara lain dalam pembelajaran guru sangat jarang memberikan kesempatan kepada siswanya untuk memahami fenomena-fenomena yang ada di sekitarnya berdasarkan konsep-konsep yang dipelajari. Kemudian alasan selanjutnya yang membuat rendahnya hasil belajar IPA siswa kelas V adalah guru kurang dapat memanfaatkan secara optimal sarana dan prasarana yang ada di sekolah.

Permasalahan-permasalahan di atas yang ditemukan oleh saya sebagai peneliti berdasarkan observasi yang dilakukan, permasalahan yang ada tersebut juga didukung oleh bukti nilai UTS siswa kelas V pada semester 1, yakni SD N 1 Kubutambahan 72,4, SD N 2 Kubutambahan 67, SD N 3 Kubutambahan 70,5, SD N 4 Kubutambahan 70,7, SD N 5 Kubutambahan 67,2, SD N 6 Kubutambahan 67,1, SD N 7 Kubutambahan 72,6. Nilai UTS yang diperoleh tersebut masih kurang dari KKM.

Hampir semua sekolah dasar di Gugus II Santalia memiliki rata-rata nilai UTS dibawah KKM. KKM yang diperoleh ini berdasarkan 
studi dokumentasi yang dilakukan oleh penulis di SD Gugus II Santalia Kecamatan Kubutambahan. Hal lain yang lebih ironis lagi, bahwa ada beberapa siswa yang mendapatkan nilai 10 , yang mana nilai ini merupakan nilai yang sangat buruk. Guru dalam melakukan penilaian hasil belajar IPA siswa, guru dalam menyusun soal belum begitu mengaplikasikan domain kognitif baik dari Bloom atau pun dari Lorin Anderson. Dewasa ini guru-guru hendaknya memahami domain kognitif dari penyusunan soal. Misalkan saja, ranah kognitif dari Bloom yang direvisi oleh Anderson. Berdasarkan wawancara yang dilakukan terhadap beberapa guru yang memegang mata pelajaran IPA kelas V, bahwasanya guru belum begitu memerhatikan ranah kognitif dari penyusunan soal. Contohnya, dalam penyusunan soal guru belum mencapai ke C6 yaitu berkreasi. Soal yang dibuat oleh guru masih kebanyakan berada di C2 yaitu memahami. Hal ini diketahui berdasarkan hasil wawancara dengan beberapa guru di Gugus II Santalia. Guru-guru tersebut menjelaskan bahwa soal yang dibuat kebanyakan berada di tingkatan ranah kognitif, yaitu pada C2 dan C3. Hal ini dikarenakan nilai rata-rata yang diperoleh siswa saja sudah sebagian di bawah KKM, itu pun soal yang diberikan tidak mencapai C4, bahkan C6. Misalkan saja jika soal yang diberikan sampai pada tingkatan C6, mungkin saja semua siswa akan mendapatkan nilai di bawah KKM. Hal lain juga, karakteristik materi yang diajarkan guru, kurang tepat jika soal yang diberikan sampai pada tingkatan C6. Hal inilah salah satu yang menyebabkan hasil belajar siswa kurang.

Dari permasalahan-permasalahan yang terjadi, ada beberapa solusi yang dapat ditawarkan untuk meminimalisir permasalahan yang ada, seperti pertama, faktor-faktor permasalahan yang muncul dalam proses pembelajaran IPA, maka diperlukan suatu penerapan pembelajaran yang membuat pembelajaran terasa menyenangkan serta hasil belajar yang akan dicapai nantinya benar-benar berguna bagi siswa. Melalui penemuan konsep secara terbimbing siswa akan dapat memahami konsep yang dipelajari secara lebih mendalam.

Salah satu model pembelajaran yang dapat diterapkan adalah Process Oriented Guided Inquiry Learning (POGIL). Piaget menyatakan prinsip utama POGIL adalah "pembelajaran yang ditingkatkan ketika siswa: 1) secara aktif terlibat, 2) berpikir, 3) menganalisis data, mendiskusikan ide-ide, menarik kesimpulan, dan membangun pengetahuan mereka sendiri 4) dan berinteraksi social" (Simonson \& Susan, 2013:56-57). POGIL dapat berdampak pada peningkatan hasil belajar siswa, hal ini dibuktikan dengan hasil penelitian yang dilakukan oleh Sulastriningsih \& Suranata (2012) hasil penelitiannya menyatakan nilai rata-rata tes kemampuan pemahaman konsep IPA pada siswa setelah mengikuti model POGIL adalah sebesar 54,7 dan berada pada kategori tinggi. Sedangkan, nilai rata-rata tes kemampuan pemahaman konsep IPA pada siswa setelah mengikuti model konvensional adalah sebesar 44,8 dan berada pada kategori tinggi. Terdapat perbedaan kemampuan pemahaman konsep siswa antara kelompok siswa yang menggunakan model pembelajaran POGIL dengan kelompok siswa yang menggunakan model konvensional.

Kedua, selain penggunaan model POGIL, hal lain yang harus diperhatikan guru dalam proses pembelajaran ialah gaya kognitif yang dimiliki siswa. Gaya kognitif merupakan "karakteristik seseorang dalam menerima, menganalisis dan merespon suatu tindakan kognitif yang diberikan. Gaya kognitif relfektif dan impulsif merupakan gaya kognitif yang menunjukkan tempo atau kecepatan dalam berpikir. Maka ide berpikir kreatif yang dihasilkan anak tergantung dari gaya kognitif yang dimiliki” (Rahmatina, 2014:63-64).

Gaya kognitif didasarkan atas "perbedaan conceptual tempo yaitu perbedaan yang didasarkan atas waktu yang digunakan untuk merespon dikenal dengan nama impulsif dan reflective" (Rahman Abdul, 2010:5).

Dalam gaya kognitif, "orang yang impulsif mengambil keputusan dengan cepat tanpa memikirkannya secara mendalam. Sebaliknya orang yang reflektif mempertimbangkan segala alternatif sebelum mengambil keputusan dalam situasi yang tidak mempunyai penyelesaian yang mudah" (Nasution, 2000:97). Jadi, seorang reflektif atau impulsif bergantung pada kecenderungan untuk merefleksi atau memikirkan alternatif-altematif pemecahan suatu masalah yang bertentangan dengan kecenderungn untuk mengambil keputusan yang impulsif dalam menghadapi masalah-masalah yang sangat tidak pasti jawabannya. 
Ketiga, dalam proses pembelajaran IPA guru sebaiknya lebih meningkatkan aktivitas siswa untuk aktif terlibat dalam setiap proses pembelajaran seperti percobaan, diskusi kelompok. Hal lainnya juga guru harus dapat mengaitkan setiap fenomena yang ada ke dalam pembelajaran dan juga dapat memanfaatkan alam sekitar sebagai salah satu sumber belajar. dalam pembelajaran IPA seorang guru dituntut untuk dapat mengajak anak didiknya memanfaatkan alam sekitar sebagai sumber belajar. Alam sekitar sebagai sumber belajar yang paling otentik dan tidak akan habis digunakan (Sudana,dkk 2010:1).

Adapun tujuan dari penelitian ini, untuk (1) mengetahui perbedaan yang signifikan hasil belajar IPA antara siswa yang mengikuti pembelajaran dengan model POGIL dan siswa yang mengikuti pembelajaran dengan pembelajaran konvensional pada siswa kelas V SD di Gugus II Santalia Kecamatan Kubutambahan Tahun Pelajaran 2015/2016, (2) mengetahui perbedaan yang signifikan hasil belajar IPA antara kelompok siswa yang memiliki gaya kognitif reflektif dan siswa yang memiliki gaya kognitif impulsif pada siswa kelas V SD di Gugus II Santalia Kecamatan Kubutambahan Tahun Pelajaran 2015/2016, dan (3) mengetahui interaksi yang signifikan antara model pembelajaran dan gaya kognitif terhadap hasil belajar IPA pada siswa kelas V di Gugus II Santalia Kecamatan Kubutambahan Tahun Pelajaran 2015/2016.

\section{METODE}

Penelitian ini merupakan penelitian eksperimen semu (quasi experiment) karena tidak semua variable yang muncul dalam kondisi eksperimen dapat diatur dan dikontrol secara ketat dengan rancangan "Post Test Only Control Design” seperti pada Gambar 1.

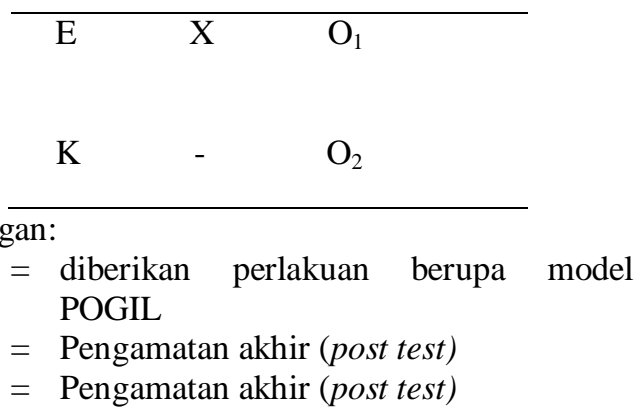

Gambar 1 Rancangan Penelitian
Dalam setiap penelitian yang akan dilakukan, populasi dan sampel sangatlah diperlukan karena akan dijadikan sebagai subjek dalam penelitian.

Penelitian ini dilaksanakan di Gugus II Santalia Kecamatan Kubutambahan dengan rentang waktu dari bulan februari sampai bulan april tahun 2016. Dalam penelitian ini yang menjadi populasi adalah semua siswa kelas $\mathrm{V}$ SD di Gugus II Santalia Kecamatan Kubutambahan yang terdiri dari 7 SD, yaitu SD N 1 Kubutambahan, SD N 2 Kubutambahan, SD N 3 Kubutambahan, SD N 4 Kubutambahan, SD N 5 Kubutambahan, SD N 6 Kubutambahan, SD N 7 Kubutambahan. Pengambilan sampel dilakukan dengan menggunakan teknik random sampling, yaitu teknik pengambilan sampel dari populasi yang dilakukan secara acak tanpa memerhatikan strata yang ada dalam populasi tersebut dan menganggap semua anggota populasi homogen. SD N 1 Kubutambahan sebagai kelompok eksperimen dan SD N 6 Kubutambahan sebagai kelompok kontrol. Penelitian ini melibatkan tiga variabel, yaitu variabel bebas, variabel terikat, dan variabel moderator. Variabel bebas dalam penelitian ini adalah model POGIL (Procces Oriented Guided Inquiry Learning), variabel terikat dalam penelitian ini adalah hasil belajar IPA, sedangkan variabel moderator dalam penelitian ini adalah gaya kognitif.

Berkaitan dengan permasalahan yang dikaji dalam penelitian ini, data tentang gaya kognitif siswa diperoleh dengan menggunakan tes gaya kognitif (MFFT). Data hasil belajar IPA siswa diperoleh dengan menggunakan tes objektif dalam bentuk pilihan ganda, yang telah diuji cobakan dan dikonsultasikan kepada ahli (expert judgement), dan dianalisis validitas tes, reliabilitas tes, daya pembeda, dan tingkat kesukaran tes.

Pengujian persyaratan analisis dilakukan sebelum mengkaji hipotesis yaitu uji normalitas sebaran data dan uji homogenitas varians dengan menggunakan bantuan SPSS 16.0 for windows. Untuk melakukan uji hipotesis menggunakan uji

ANAVA AB, yang bertujuan untuk mengetahui 1) apakah terdapat perbedaan hasil belajar IPA antara kelompok siswa yang dibelajarkan dengan model POGIL dan pembelajaran konvensional, (2) apakah terdapat perbedaan hasil belajar IPA antara kelompok siswa yang memiliki gaya kognitif reflektif dan impulsif, 
(3) apakah terdapat interaksi antara model pembelajaran POGIL dan gaya kognitif terhadap hasil belajar IPA.

\section{HASIL DAN PEMBAHASAN}

\section{Hasil}

Hasil nilai rata-rata hasil belajar IPA pada kelompok siswa dengan gaya kognitif reflektif yang dibelajarkan dengan model POGIL berjumlah 15 siswa menunjukkan bahwa skor tertinggi adalah 100 dan skor terendah adalah 70 dengan mean 79,06, median 73,00 dan modus 70,00. Berdasarkan hasil konversi pada skala penilaian, jika nilai rata-rata hasil belajar IPA kelompok siswa dengan gaya kognitif reflektif yang dibelajarkan dengan model POGIL maka tergolong ke dalam kategori sangat tinggi.

Hasil nilai rata-rata hasil belajar IPA pada kelompok siswa dengan gaya kognitif impulsif yang dibelajarkan dengan model POGIL berjumlah 15 siswa menunjukkan bahwa skor tertinggi adalah 80 dan skor terendah adalah 50 dengan mean 60,13 , median 56,00 dan modus 50,00. Berdasarkan hasil konversi pada skala penilaian, jika nilai rata-rata hasil belajar IPA kelompok siswa dengan gaya kognitif impulsif yang dibelajarkan dengan model POGIL maka tergolong ke dalam kategori tinggi.

Hasil nilai rata-rata hasil belajar IPA pada kelompok siswa dengan gaya kognitif reflektif yang dibelajarkan dengan pembelajaran konvensional berjumlah 15 siswa menunjukkan bahwa skor tertinggi adalah 86 dan skor terendah adalah 50 dengan mean 62,80 , median 60,00 dan modus 50,00. Berdasarkan hasil konversi pada skala penilaian, jika nilai rata-rata hasil belajar IPA kelompok siswa dengan gaya kognitif reflektif yang dibelajarkan dengan pembelajaran konvensional maka tergolong ke dalam kategori tinggi.

Hasil nilai rata-rata hasil belajar IPA pada kelompok siswa dengan gaya kognitif impulsif yang dibelajarkan dengan pembelajaran konvensional berjumlah 15 siswa menunjukkan bahwa skor tertinggi adalah 46 dan skor terendah adalah 6 dengan mean 30,60, median 30,00 dan modus 30,00. Berdasarkan hasil konversi pada skala penilaian, jika nilai rata-rata hasil belajar IPA kelompok siswa dengan gaya kognitif impulsif yang dibelajarkan dengan pembelajaran konvensional maka tergolong ke dalam kategori rendah.

Data hasil belajar IPA antara kelompok siswa dengan gaya kognitif reflektif dan impulsif yang dibelajarkan dengan model POGIL dan kelompok siswa dengan gaya kognitif reflektif dan impulsif yang dibelajarkan dengan pembelajaran konvensional berdistribusi normal.

Data hasil belajar IPA antara kelompok model POGIL dan kelompok pembelajaran konvensional adalah homogen. Selanjutnya, data hasil belajar IPA antara kelompok gaya kognitif reflektif dan kelompok gaya kognitif impulsif adalah homogen.

Dari hasil uji prasyarat, yaitu uji normalitas dan homogenitas diperoleh bahwa data dari kelompok eksperimen dan kelompok kontrol berdistribusi normal dan homogen. Berdasarkan hal tersebut, maka dapat dilanjutkan dengan menguji hipotesis pertama, kedua, dan ketiga dengan menggunakan analisis varians dua jalur (Anava $\mathrm{AB}$ ) dibantu dengan SPSS 16.0 For Windows disajikan pada Tabel 1.

Tabel 1 Rangkuman Hasil Pehitungan ANAVA AB

\begin{tabular}{|c|c|c|c|c|c|c|}
\hline $\begin{array}{c}\text { Sumber } \\
\text { Varian }\end{array}$ & JK & db & RJK & F Hitung & $\begin{array}{l}\text { F Tabel } \\
(\alpha \quad 0,05)\end{array}$ & Ket \\
\hline $\mathrm{A}$ & 7866,150 & 1 & 7866,150 & 64,736 & 4,00 & Signifikan \\
\hline $\mathrm{B}$ & 9804,817 & 1 & 9804,817 & 80,690 & 4,00 & Signifikan \\
\hline Inter $\mathrm{AB}$ & 660,017 & 1 & 660,017 & 5,432 & 4,00 & Signifikan \\
\hline Dalam & 6804,667 & 56 & 121,512 & - & - & \\
\hline Total & 25135,650 & 59 & - & - & - & \\
\hline
\end{tabular}

kelompok siswa yang dibelajarkan dengan model POGIL dan kelompok siswa yang 


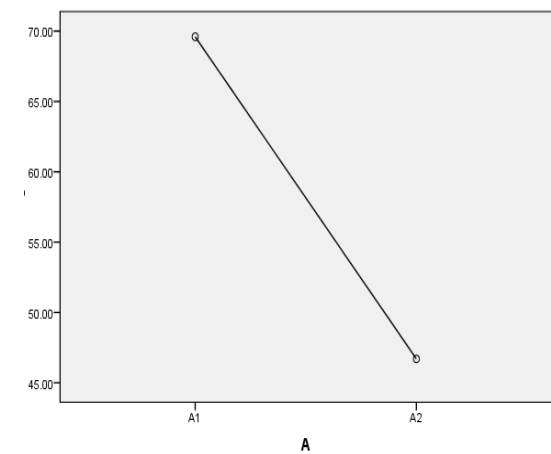

Gambar 2 Grafik Nilai Rata-rata Hasil Belajar IPA antara Siswa yang dibelajarkan dengan Model POGIL dan Siswa yang dibelajarkan dengan Pembelajaran Konvensional

Berdasarkan Gambar 2, dapat dijelaskan bahwa kelompok siswa yang dibelajarkan dengan mdel POGIL memiliki nilai rata-rata hasil belajar IPA sebesar 69,90. Sedangkan, kelompok siswa yang dibelajarkan dengan pembelajaran konvensional memiiki nilai ratarata hasil belajar IPA sebesar 46,70. Hal ini menunjukkan bahwa hasil belajar IPA siswa yang dibelajarkan dengan model POGIL lebih baik daripada hasil belajar IPA siswa yang dibelaarkan dengan pembelajaran konvensional. 2) terdapat perbedaan yang signifikan hasil belajar IPA antara kelompok siswa yang memiliki gaya kognitif reflektif dan kelompok siswa yang memiliki gaya kognitif impulsive $\left(F_{\text {hitung }}>F_{\text {tabel }}\right.$ yaitu $80,690>4,00$ pada taraf signifikansi 5\%).

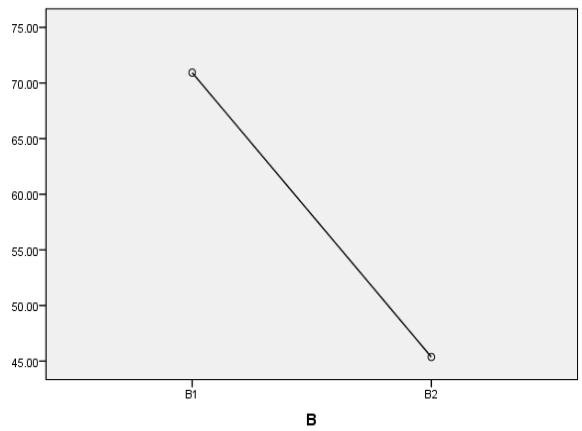

Gambar 3 Grafik Nilai Rata-rata Hasil Belajar IPA antara Kelompok Siswa dengan Gaya Kognitif Reflektif dan Kelompok Siswa dengan Gaya Kognitif Impulsif

Berdasarkan Gambar 3, dapat dijelaskan bahwa kelompok siswa yang memiliki gaya kognitif reflektif memiliki nilai rata-rata hasil belajar IPA sebesar 70,93. Sedangkan, kelompok siswa yang memiliki gaya kognitif impulsif memiliki nilai rata-rata sebesar 45,36. Hal ini menunjukkan bahwa hasil belajar IPA kelompok siswa yang memiliki gaya kognitif reflektif lebih baik daripada kelompok siswa yang memiliki gaya kognitif impulsif. 3) terdapat interaksii yang signifikan antara model pembelajaran POGIL dan gaya kognitif terhadap hasill belajar IPA $\left(\mathrm{F}_{\text {hitung }}>\mathrm{F}_{\text {tabel }}\right.$ yaitu $5,432>$ 4,00 pada taraf signifikansi $5 \%$ ).

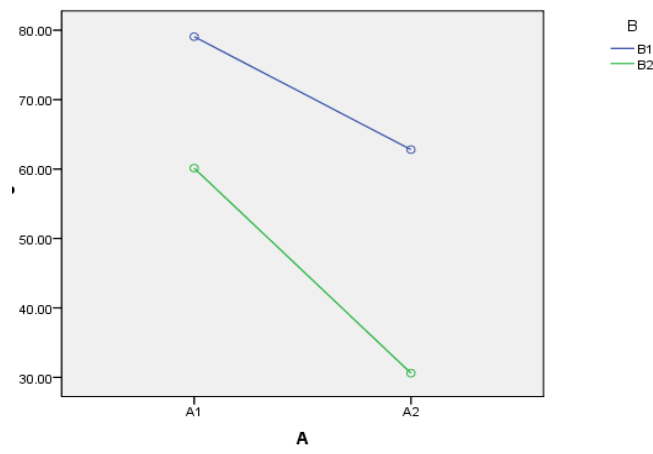

\section{Gambar 4 Interaksi antara Model Pembelajaran dengan Gaya Kognitif}

Berdasarkan Gambar 4, dapat dijelaskan bahwa siswa dengan gaya kognitif reflektif akan memperoleh hasil belajar IPA yang optimal/lebih baik jika dibelajarkan dengan model POGIL. Hal ini terbukti pada nilai ratarata hasil belajar IPA yang diperoleh, yaitu sebesar 79,06 yang mana jika dikonversikan ke dalam skala lima termasuk ke dalam kategori sangat tinggi. Kemudian untuk siswa impulsif yang dibelajarkan dengan model POGIL memiliki nilai rata-rata hasil belajar IPA sebesar 60,13 . Selanjtunya, untuk siswa reflektif yang dibelajarkan dengan pembelajaran konvensional memiliki nilai rata-rata hasil belajar IPA sebesar 62,80. Untuk siswa impulsif yang dibelajarkan dengan pembelajaran konvensional memiliki nilai rata-rata hasil belajar IPA sebesar 30,60. Kelompok siswa yang memiliki gaya kognitif reflektif dibelajarkan dengan model POGIL maka akan memperoleh hasil belajar IPA yang lebih baik. Sedangkan, untuk kelompok siswa dengan gaya kognitif impulsif yang dibelajarkan dengan pembelajaran konvensional akan memperoleh hasil belajar IPA yang kurang optimal. Jadi, dapat disimpulkan bahwa model pembelajaran dan gaya kognitif memiliki 
interaksi yang akan memengaruhi hasil belajar IPA siswa.

\section{Pembahasan}

Berdasarkan hasil analisis data, ada beberapa temuan yang diperoleh. Pertama terdapat perbedaan hasil belajar IPA antara kelompok siswa yang dibelajarkan dengan model POGIL dan pembelajaran konvensional. Nilai rata-rata yang diperoleh antara kelompok siswa yang dibelajarkan dengan model POGIL dan kelompok siswa yang dibelajarkan dengan pembelajaran konvensional itu berbeda. Nilai rata-rata yang diperoleh oleh kelompok siswa yang dibelajarkan dengan model POGIL memiliki nilai rata-rata yang lebih tinggi dibandingkan dengan kelompok siswa yang dibelajarkan dengan pembelajaran konvensional. Hal ini dikarenakan perbedaan langkah-langkah dalam pembelajarannya. Dalam model POGIL siswalah yang lebih aktif dalam proses pembelajaran dibandingkan dengan kelompok siswa yang mengikuti pembelajaran konvensional, yakni guru lebih banyak menguasai pembelajaran.

Hal ini sejalan dengan pendapat Hanson (2006) yang menyatakan bahwa POGIL merupakan kegiatan belajar yang melibatkan siswa, mempromosikan restrukturisasi (penataan kembali) informasi dan pengetahuan dan membantu siswa mengembangkan pemahaman dengan menggunakan siklus belajar di dipandu kegiatan penyelidikan. Selain itu, Barthlow (2011) juga menyatakan bahwa salah satu tujuan pembelajaran POGIL adalah melibatkan para siswa untuk aktif terlibat dalam proses pembelajaran.

Sejalan dengan pendapat di atas, Hanson (2006) juga menyatakan kelebihan model POGIL ialah: 1) membangun pengetahuan mereka sendiri berdasarkan pengetahuan sebelumnya. 2) aktif terlibat dan berpikir di kelas dan laboratorium. 3) mengambil kesimpulan dengan menganalisis data, model, atau contoh-contoh dengan berdiskusi.

Hal ini sejalan dengan pendapat Sulastriningsih \& Suranata (2012) hasil penelitiannya menyatakan nilai rata-rata tes kemampuan pemahaman konsep IPA pada siswa setelah mengikuti model POGIL adalah sebesar 54,7 dan berada pada kategori tinggi. Sedangkan, nilai rata-rata tes kemampuan pemahaman konsep IPA pada siswa setelah mengikuti model konvensional adalah sebesar 44,8 dan berada pada kategori tinggi. Terdapat perbedaan kemampuan pemahaman konsep siswa antara kelompok siswa yang menggunakan model pembelajaran POGIL dengan kelompok siswa yang menggunakan model konvensional.

Kedua, terdapat perbedaan hasil belajar IPA antara kelompok siswa yang memiliki gaya kognitif reflektif dan impulsive. Nilai rata-rata hasil belajar IPA yang diperoleh kelompok siswa dengan gaya kognitif reflektif yang dibelajarkan dengan model POGIL ataupun yang dibelajarkan dengan pembelajaran konvensional memiliki nilai rata-rata hasil belajar IPA yang lebih tinggi dibandingkan dengan kelompok siswa dengan gaya kognitif impulsif yang dibelajarkan dengan model POGIL ataupun yang dibelajarkan dengan pembelajaran konvensional. Hal ini dikarenakan siswa yang memiliki gaya kognitif reflektif lebih mempertimbangkan jawaban sebelum merespon suatu hal ataupun dengan kata lain siswa reflektif sangat hati-hati dalam memberikan jawabannya dibandingkan engan siswa yang memiliki gaya kognitif impulsive yang sangat tergesa-gesa dalam merespon suatu hal.

Dalam proses pembelajaran guru hendaknya memehatikan gaya kgnitif siswa yang dimiliki. Gaya kognitif merupakan salah satu dari faktor yang apat memenaruhi hasil belajar. Setiap individu dalam hal ini siswa pada dasarnya memiliki kondisi psikologis yang berbeda-beda, tentunya hal ini turut memengaruhi hasil beajarnya. Beberapa faktor psikologis meliputi intelegensi (IQ), gaya kognitif, dan lain sebagainya (Rusman, 2015).

Hal ini sejalan dengan pendapat Nasution (2000) yang menyatakan bahwa orang yang impulsif mengambil keputusan dengan cepat tanpa memikirkannya secara mendalam. Sebaliknya orang yang reflektif mempertimbangkan segala alternatif sebelum mengambil keputusan dalam situasi yang tidak mempunyai penyelesaian yang mudah. Jadi, seorang reflektif atau impulsif bergantung pada kecenderungan untuk merefleksi atau memikirkan alternatif-altematif pemecahan suatu masalah yang bertentangan dengan kecenderungn untuk mengambil keputusan yang impulsif dalam menghadapi masalah-masalah yang sangat tidak pasti jawabannya. 
Ketiga, terdapat interaksi antara model pembelajaran POGIL dan gaya kognitif terhadap hasil belajar IPA. Nilai rata-rata hasil belajar IPA yang diperoleh, yaitu sebesar 79,06 yang mana jika dikonversikan ke dalam skala lima termasuk ke dalam kategori sangat tinggi. Kemudian untuk siswa impulsif yang dibelajarkan dengan model POGIL memiliki nilai rata-rata hasil belajar IPA sebesar 60,13. Selanjtunya, untuk siswa reflektif yang dibelajarkan dengan pembelajaran konvensional memiliki nilai rata-rata hasil belajar IPA sebesar 62,80. Untuk siswa impulsif yang dibelajarkan dengan pembelajaran konvensional memiliki nilai rata-rata hasil belajar IPA sebesar 30,60.

Kelompok siswa yang memiliki gaya kognitif reflektif dibelajarkan dengan model POGIL maka akan memperoleh hasil belajar IPA yang lebih baik. Sedangkan, untuk kelompok siswa dengan gaya kognitif impulsif yang dibelajarkan dengan pembelajaran konvensional akan memperoleh hasil belajar IPA yang kurang optimal.

Gaya kognitif dan model pembelajran yang diterapkan oleh guru akan sangat berpengaruh terhadap hasil belajar IPA siswa. Interaksi antara model pembelajaran dengan gaya kognitif memiliki interaksi yang erat. Seperti halnya dijelaskan di atas, guru dalam proses pembelajaran tidak boleh hanya memikirkan model pembelajaran yang tepat untuk diterapkan.

Namun, dewasa ini guru juga harus lebih memerhatikan faktor psikologis siswa seperti gaya kognitif yang dimiliki siswa. Seperti halnya dalam penelitian ini, kelompok siswa yang memiliki gaya kognitif reflektif yang dibelajarkan dengan model POGIL memiliki nilai rata-rata hasil belajar IPA yang sangat tinggi. Begitu juga sama halnya dengan siswa yang memiliki gaya kognitif impulsif yang dibelajarkan dengan model POGIL memiliki nilai rata-rata hasil belajar IPA yang tinggi. Kemudian untuk siswa yang memilki gaya kognitif reflektif yang dibelajarkan dengan pembelajaran konvensional memiliki nilai ratarata hasil belajar IPA yang tinggi, sedangkan siswa dengan gaya kognitif impulsif yang dibelajarkan dengan pembelajaran konvensional memiliki nilai rata-rata hasil belajar IPA rendah. Hal ini berarti bahwa siswa yang memiliki gaya kognitif reflektif jika dibelajarkan dengan model POGIL ataupun yang dibelajarkan dengan pembelajaran konvensional sama-sama dapat mempengaruhi hasil belajar IPA ke arah yang lebih baik.

Hal di atas dapat dikarenakan siswa yang memiliki gaya kognitif reflektif dalam memberikan suatu pendapatnya dalam suatu hal dipikirkan secara mendalam, tidak asal memberikan jawabannya. Sedangkan, untuk siswa yang memiliki gaya kognitif impulsif yang dibelajarkan dengan model POGIL ataupun yang dibelajarkan dengan pembelajaran konvensional sama-sama memberikan pengaruh terhadap hasil belajar IPA. Namun, siswa yang memiliki gaya kognitif impulsif cenderung memberikan jawabannya dengan cepat tanpa memikirkan jawabannya secara mendalam. Intinya, gruru dalam merancang sebuah pembelajaran harus benar-benar memerhatikan model pembelajaran yang tepat dan memerhatikan gaya kognitif siswa dengan baik.

Berdasarkan pemaparan di atas, dapat disimpulkan bahwa penerapan model POGIL (Process Oriented Guided Inquiry Learning) ditinjau dari gaya kognitif berpengaruh terhadap hasil belajar IPA.

\section{SIMPULAN}

Berdasarkan paparan hasil peneitian dan pembahasan dapat disimpulkan bahwa pertama, terdapat perbedaan hasil belajar IPA yang signifikan antara kelompok siswa yang mengikuti pembelajaran dengan model POGIL dan kelompok siswa yang mengikuti pembelajaran dengan pembelajaran konvensional. Hal ini dapat dilihat dari rata-rata nilai hasil belajar IPA siswa yang mengikuti pembelajaran dengan model POGIL lebih tinggi daripada kelompok siswa yang mengikuti pembelajaran dengan pembelajaran konvensional.

Kedua, terdapat perbedaan yang signifikan hasil belajar IPA siswa antara siswa yang memiliki gaya kognitif reflektif dan impulsif antara kelompok siswa yang dibelajarkan dengan model POGIL, yaitu SD N 1 Kubutambahan maupun kelompok siswa yang dibelajarkan dengan pembelajaran konvensional, yaitu SD N 6 Kubutambahan. Nilai rata-rata hasil belajar IPA yang diperoleh oleh kelompok siswa dengan gaya kognitif reflektif baik dari siswa yang dibelajarkan dengan model POGIL ataupun pembelajaran konvensional lebih tinggi daripada kelompok siswa dengan gaya kognitif impulsif baik dari 
siswa yang dibelajarkan dengan model POGIL ataupun pembelajaran konvensional.

Ketiga terdapat interaksi yang signifikan antara model pembelajaran dengan gaya kognitif. Hal ini dapat dilihat dari hasil analisis data yang menunjukkan bahwa $\alpha>$ signifikansi, dengan $\alpha=0,05$ dan signifikansi $=$ 0,024 . Kelompok siswa dengan gaya kognitif reflektif yang dibelajarkan dengan pembelajaran konvensional dengan kelompok siswa dengan gaya kognitif impulsive yang dibelajarkan dengan model POGIL memiliki nilai rata-rata hasil belajar IPA hampir sama. Namun, nilai rata-rata hasil belajar IPA yang dimiliki oleh kelompok siswa dengan gaya kognitif reflektif lebih tinggi daripada nilai rata-rata hasil belajar IPA yng dimiliki oleh kelompom siswa dengan gaya kognitif impulsive. Hal ini dikarenakan kelompok siswa dengan gaya kognitif reflektif sangat mempertimbangkan atau dengan kata lain memikirkan secara mendalam jawaban yang akan diberikan.

Berdasarkan penelitian yang dilakukan bahwasanya model POGIL dapat memengaruhi hasil belajar IPA. Kelompok siswa dengan gaya kognitif reflektif yang dibelajarkan dengan model POGIL ataupun yang dibelajarkan dengan pembelajaran konvensional memiliki nilai rata-rata yang lebih tinggi dibandingkan dengan kelompok siswa yang memiliki gaya kognitif impulsif yang dibelajarkan dengan model POGIL ataupun yang dibelajarkan dengan pembelajaran konvensional.

Pada penelitian ini, baru hanya dilakukan pada materi cahaya dan tanah ada kelas V. Untuk peneliti lain yang ingin meneliti hasil belajar IPA dengan menggunakan model POGIL dapat mengambil materi pelajaran yang lain, guna memberikan hasil yang beragam dan lebih baik.

\section{DAFTAR RUJUKAN}

Barthlow, M.J. 2011. "The Effectiveness Of Process Oriented Guided Inquiry Learning To Reduce Alternate Conceptions In Secondary Chemistry". Lynchburg: Liberty University. Tersedia pada:

http://onlinelibrary.wiley.com/doi/10.111

1/ssm.12076/abstract. Diakses pada tanggal 11 November 2015.
B. Uno, Hamzah. 2011. Profesi Kependidikan. Jakarta:Bumi Aksara.

Hanson, D.M. 2006. "Instructor's Guide to Pocess-Oriented Guided-Inquiry Learning”. Lisle. Pacific Grest. Tersedia pada:

https://pogil.org/uploads/media_items/po gil-instructor-s-guide-1.original.pdf.

Diakses pada 11 November 2015.

Ibnu, Trianto Badar Al-Tabany. 2014. Mendesain Model Pembelajaran Inovatif, Progresif, dan Kontekstual. Jakarta: Prenamedia Group.

Nasution, S. 2000. Berbagai Pendekatan dalam Proses Belajar \& Pembelajaran. Jakarta: Bumi Aksara.

Rahmatina, Siti. 2014. "Tingkat Berpikir Kreatif Siswa dalam Menyelesaikan Masalah Matematika Berdasarkan Gaya Kognitif Reflektif dan Impulsif”. Jurnal Didakti Matematika. Tersedia pada: http://download.portalgaruda.org/article.p hp $?$ article $=157640 \&$ val $=5828 \&$ title $=$ Ting kat\%20Berpikir\%20Kreatif\%20Siswa\%2 0dalam\%20Menyelesaikan\%20Masalah\% 20Matematika\%20Berdasarkan\%20Gaya \%20Kognitif\%20Reflektif\%20dan\%20Im pulsif Diakses pada: 11 November 2015.

Rusman. 2015. Pembelajaran Tematik Terpadu. Jakarta: PT Raja Grafindo Persada.

Simonson, Shawn. R. \& Susan, E. Shadle. 2013. "Implementing Process Oriented Guided Inquiry Learning (POGIL) in Undergraduated Biomechanics: Lessons Learned by A Novice". Boise State University. Tersedia pada: http://scholarworks.boisestate.edu/kinesio logy_facpubs/113/. Diakses pada: 11 November 2015.

Sudana, Nyoman. Dewa, dkk. 2010. Pendidikan $I P A$ di SD. Singaraja: UNDIKSHA PRESS. 
Sulastriningsih, P. \& K. Suranata. 2012. "Pengaruh Model Process Oriented Guided Inquiry Learning Terhadap Kemampuan Pemahaman Konsep IPA Siswa Kelas V SD Gugus IX Kecamatan Buleleng. Jurnal Undiksha. Tersedia pada:

http://ejournal.undiksha.ac.id/index.php/J JPGSD/article/viewFile/820/693. Diakses pada: 11 November 2015.

Susanto, Ahmad. 2013. Teori Belajar dan Pembelajaran di Sekolah Dasar. Jakarta: Prenadamedia Group. 